\title{
Analysis of the training needs, preference and constraints of marginal and small poultry farmers of Bareilly district
}

\author{
R. HARI, NEERAJ KUMAR SHARMA AND HEMA TRIPATHI
}

\begin{abstract}
A study was conducted to assess the training needs, preference and constraints of small and marginal farmers of Bareilly District of Uttar Pradesh. Fifty poultry farmers were selected using snowball sampling technique from the Bhojipura Block of Bareilly district. They were interviewed with structured schedule prepared beforehand. Data on training needs were analysed based on Training Need Index of each major and minor farm operation. Training preference were analysed using percentage score and the constraints using mean score Out of the major operations studied farmers preferred housing as the one in which they require training needs. Knowledge and financial needs were also very much relevant to the farmers. Farmers preferred on farm neighbourhood training, in forenoon and in the months between March and May. Farm visit is the most desired method of training as perceived by the farmers. Feeding and breeding problems were the chief constraints perceived by the farmers.
\end{abstract}

KEY WORDS : Training Needs, Preference, Constraints, Poultry farmers

How to CITE THIS PAPER : Hari, R. Sharma, Neeraj Kumar and Tripathi, Hema (2014). Analysis of the training needs, preference and constraints of marginal and small poultry farmers of Bareilly district. Res. J. Animal Hus. \& Dairy Sci., 5(2) : 88-91.

Address for correspondence :

R. Hari, Division of Extension Education, Indian Veterinary Research Institute, Izatnagar, BAREILLY (U.P.) INDIA

Email : hariptr84@gmail.com

Associated Authors' :

Neeraj Kumar Sharma, Division of Extension Education, Indian Veterinary Research Institute, Izatnagar, BAREILLY (U.P.) INDIA

Hema Tripathi, Krishi Vigyan Kendra, BAREILLY (U.P.) INDIA 